\title{
ANALISIS KONTRIBUSI DAN EFEKTIVITAS PAJAK DAERAH SEBAGAI SUMBER PENDAPATAN ASLI DAERAH (PAD) DI KOTA BITUNG
}

\author{
Cindy Y. Wenur ${ }^{1}$, Inggriani Elim², Steven J. Tangkuman ${ }^{3}$ \\ ${ }^{1,2,3}$ Fakultas Ekonomi dan Bisnis, Jurusan Akuntansi, Universitas Sam Ratulangi, J1.Kampus Bahu. Manado, \\ 95115, Indonesia \\ Email : cindyywenur@gmail.com
}

\begin{abstract}
Locally-generated revenue (PAD) is all income obtained locally and collected based on prevailing laws and regulations. PAD sourced by local taxes, local retribution, management result of separated regional wealth, and other legitimate PAD. Local taxes is a tax which collected and managed by the government and used to finance regional development. Local taxes is a potential component to increase PAD. This study aims to know how much the contribution of local taxes as a source of PAD and to know the effectiveness of local taxes in Bitung City. This study was conducted on Badan Pengelola Pajak dan Retribusi Daerah. The results show that the contribution of local taxes as a source of PAD in Bitung City during the period 2013-2017 is in good category with an average contribution 40,98\% per year. The biggest contribution from street lighting tax and the lowest contribution from swallow nest tax. As for the effectiveness of local taxes during the period 2013-2017 is in very effective category with a percentage more than $100 \%$ each year.
\end{abstract}

Keywords: contribution, effectiveness, local taxes, locally-generated revenue.

\section{PENDAHULUAN}

Di Indonesia, kegiatan pembangunan yang awalnya menekankan pada kekuatan pemerintah pusat mulai berubah pada pembangunan yang menekankan kekuatan daerah sebagai inti pembangunan. Pembangunan daerah diperlukan untuk menjamin bahwa pelaksanaan kegiatan pembangunan benar-benar dapat dinikmati oleh masyarakat, di mana pembangunan yang dilaksanakan harus sesuai dengan arah pembangunan nasional yang dituju. Sehubungan dengan pembangunan yang dilaksanakan di daerah, pemerintah daerah membutuhkan ketersediaan dana yang cukup. Oleh karena itu, mulai dikembangkan otonomi daerah secara luas, nyata, dan bertanggung jawab serta peningkatan upaya pemberdayaan masyarakat untuk mendorong pembangunan daerah. Dengan adanya sistem otonomi daerah, setiap daerah dituntut untuk lebih mandiri baik dalam tugas menjalankan pemerintahannya maupun dalam mendanai keuangan daerahnya. Untuk mewujudkan kemandirian daerah tersebut, maka pemerintah daerah diberikan kewenangan yang lebih luas dalam menggali dan mengoptimalkan potensi daerah yang dimiliki sehingga dapat menjadi sumber penerimaan daerah.

Salah satu sumber penerimaan daerah adalah Pendapatan Asli Daerah (PAD). PAD merupakan semua pendapatan yang diperoleh daerah secara lokal dan dipungut berdasarkan peraturan perundang-undangan yang berlaku. Semakin besar pemerintah memperoleh dan menghimpun penerimaan PAD maka semakin besar pula ketersediaan dana yang dapat digunakan dalam membiayai penyelenggaraan pembangunan daerah. Adapun pajak daerah merupakan komponen yang potensial untuk dikembangkan dan menjadi faktor pendorong pertumbuhan PAD. Dilihat dari komponen pembentuk PAD dalam APBD Provinsi dan Kabupaten/Kota se-Indonesia tahun anggaran 2016, kontribusi terbesar berasal dari pajak daerah yaitu sebesar Rp160,15 triliun $(69,74 \%)$, diikuti oleh lain-lain PAD yang sah sebesar Rp50,14 triliun (21,84\%), retribusi daerah sebesar Rp11,78 triliun (5,13\%), dan hasil 
pengelolaan kekayaan yang dipisahkan sebesar Rp7,56 triliun (3,29\%) (Direktorat Jenderal Bina Keuangan Daerah Kementerian Dalam Negeri, 2016). Oleh sebab itu, management pajak daerah harus dilakukan dengan baik dalam rangka meningkatkan kontribusi pajak daerah dan optimalisasi PAD.

Kota Bitung yang terletak di Provinsi Sulawesi Utara juga merupakan salah satu kota yang melaksanakan otonomi daerah. Dengan ragam potensi kekayaan alam yang dimiliki, Kota Bitung menjadi salah satu kota yang mengalami pertumbuhan cukup pesat dengan empat potensi utama yaitu di bidang perikanan, pariwisata, industri dan pertanian. Dalam perkembangannya, perekonomian Kota Bitung didominasi oleh kegiatan industri perikanan, galangan kapal dan industri minyak kelapa. Dengan luas kawasan industri 512 ha yang terletak di Kota Bitung, maka pemerintah menetapkan kawasan ini sebagai salah satu Kawasan Ekonomi Khusus (KEK) di Indonesia. Dengan potensi-potensi dan perkembangan yang ada, maka diharapkan dapat menjadi sumber penerimaan yang besar bagi Kota Bitung.

\section{TINJAUAN PUSTAKA}

Pengertian Akuntansi. Menurut Accounting Principles Board, akuntansi ialah kegiatan (jasa) yang fungsinya memberikan informasi yang bersifat keuangan yang digunakan untuk pengambilan keputusan atas suatu entitas (Sodikin dan Riyono, 2016:1).

Pengertian Pajak. Undang-Undang Nomor 16 Tahun 2009 tentang Ketentuan Umum Perpajakan menyatakan pajak merupakan kontribusi orang pribadi atau badan yang dilakuan secara wajib kepada Negara dengan tidak mendapat imbalan secara langsung, yang bersifat memaksa berdasarkan Undang-undang dan digunakan untuk keperluan Negara bagi sebesarbesarnya kemakmuran rakyat.

Pajak Daerah. Menurut Supramono dan Damayanti (2010:6), pajak daerah terdiri dari pajak provinsi dan pajak kabupaten/kota yang dikumpulkan oleh pemerintah daerah dan dipakai untuk membiayai pengeluaran daerah.

Pendapatan Asli Daerah. Anggoro (2017:18) mengemukakan bahwa Pendapatan Asli Daerah (PAD) merupakan pendapatan yang diperoleh pemerintah daerah atas pelaksanaan kegiatan pemerintahan dan pelayanan kepada masyarakat, serta pemanfaatan sumber daya yang dimiliki oleh pemerintah daerah.

Kontribusi. Kamus Besar Bahasa Indonesia menjelaskan bahwa kontribusi adalah uang iuran atau sumbangan. Lalu, Mahmudi (2010:145) menjelaskan fungsi dari kontribusi yaitu untuk melihat sejauh mana pajak daerah memberikan sumbangan terhadap penerimaan pendapatan asli daerah, jika hasilnya semakin besar maka peranan pajak daerah juga semakin besar. Untuk menghitung kontribusi, dilakukan perbandingan penerimaan pajak daerah pada periode tertentu.

Efektivitas. Efektivitas adalah relasi suatu output terhadap pencapaian suatu sasaran dan/atau tujuan. Dikatakan efektif bila prosedur kegiatan tersebut memperoleh sasaran/tujuan akhir kebijakan (spending wisely). Semakin efektif proses kerja suatu unit organisasi, berarti capaian sasaran/tujuan yang dituju atas output yang dihasilkan semakin besar (Mahmudi, 2010:143).

Penelitian Terdahulu. Octovido, Sudjana, dan Azizah (2014) dengan judul penelitian "Analisis Efektivitas dan Kontribusi Pajak Daerah Sebagai Sumber Pendapatan Asli Daerah Kota Batu". Penelitian ini bertujuan untuk melihat bagaimana kontribusi dan efektivitas pajak daerah sebagai sumber pendapatan asli daerah di Kota Batu. Metode penelitian yang dipakai ialah metode deskriptif. Adapun hasil penelitian ini yaitu tingkat efektivitas pajak daerah kota Batu dari tahun 2009-2013 berfluktuasi, di mana pada tahun 2012 tingkat efektivitasnya adalah yang tertinggi yakni sebesar 136,67\% dan pada tahun 2010 adalah efektivitas terendah yakni sebesar 69,30\%. Sedangkan tingkat kontribusi pajak daerah kota Batu selama 5 tahun secara umum masuk dalam kategori baik yang dimana rata-rata kontribusinya diatas $50 \%$. 
Kontribusi terkecil terjadi pada tahun 2009 yakni 45,21\% dan terbesar pada tahun 2012 yakni $72,66 \%$. Persamaan penelitian ini dengan penelitian yang dilakukan yaitu menganalisis kontribusi dan efektivitas pajak daerah terhadap PAD, sedangkan perbedaannya terletak pada objek penelitian. Puspitasari dan Rohman (2014) dengan penelitian "Analisis Efektivitas, Efisiensi, dan Kontribusi Pajak dan Retribusi Daerah Terhadap Peningkatan PAD Kabupaten Blora Tahun 2009-2013. Tujuan dari penelitian ini untuk menganalisis esfisiensi dan efektivitas pajak daerah dan retribusi daerah, lalu dianalisis kontribusinya terhadap PAD di Kabupaten Blora. Metode penelitian yang digunakan adalah deskriptif kuantitatif. Adapun hasil penelitian ini yaitu: 1) pemerintah daerah belum mengoptimalkan potensi pajak daerah terhadap target yang ditentukan; 2) untuk potensi retribusi daerah yang ada, sudah dimanfaatkan tetapi belum bisa direalisasikan dengan baik; 3) walaupun efektivitas pajak daerah masih mengalami fluktuasi namun masuk dalam kategori yang sangat efektif. Sedangkan rata-rata efektivitas retribusi daerah masuk kategori sangat efektif; 4) selama 5 tahun, efisiensi pajak dan retribusi daerah masuk dalam kategori efisien; 5) kontribusi pajak daerah terhadap PAD masih mengalami fluktuasi dengan rata-rata kontribusi masih dibawah $20 \%$, sedangkan kontribusi retribusi daerah cenderung mengalami penurunan dengan kategori sedang; 6) untuk efektivitas serta efisiensi pajak dan retribusi daerah melalui analisis uji beda t-test menghasilkan hal yang sama. Persamaan penelitian ini dengan penelitian yang dilakukan yakni menganalisis kontribusi pajak daerah terhadap PAD. Adapun perbedaannya terletak pada objek penelitian serta penelitian yang dilakukan tidak meneliti tentang efisiensi dan retribusi daerah.

\section{METODE PENELITIAN}

Jenis Penelitian. Jenis penelitian ini adalah penelitian kualitatif. Pada penelitian ini penulis akan mengamati serta menghitung kontribusi dan efektivitas pajak daerah sebagai sumber PAD di Kota Bitung.

Tempat dan Waktu Penelitian. Penelitian ini dilaksanakan pada Badan Pengelola Pajak dan Retribusi Daerah (BP2RD) kota Bitung, yang beralamat di Jln Sam Ratulangi No. 45, Maesa, Kota Bitung. Penelitian dilakukan pada bulan Juli tahun 2018.

Jenis Data. Jenis data yang dipakai dalam penelitian ini, yaitu:

1. Data Kualitatif. Data kualitatif dalam penelitian ini ialah gambaran umum serta visi dan misi BP2RD Kota Bitung.

2. Data Kuantitatif. Data kuantitatif dalam penelitian ini adalah data realisasi PAD tahun 2013-2017, data realisasi pajak daerah tahun 2013-2017, dan data realisasi masingmasing jenis pajak daerah tahun 2013-2017.

Sumber Data. Sumber data yang dipakai dalam penelitian ini adalah data sekunder. Data sekunder merupakan data yang dipublikasikan kepada masyarakat pengguna data yang telah dikumpulkan oleh lembaga pengumpul data. Adapun data sekunder dalam penelitian ini yaitu data yang didapat dari instansi terkait, dalam hal ini BP2RD kota Bitung.

\section{Metode Pengumpulan data}

1. Dokumentasi

2. Studi Kepustakaan

Metode Analisis. Metode analisis yang dipakai untuk penelitian ini ialah metode analisis deskriptif yaitu menguraikan dan mendeskripsikan data-data yang diperoleh dilapangan, kemudian dari data-data tersebut akan dilakukan suatu analisa mengenai kontribusi dan efektivitas pajak daerah sebagai sumber pendapatan asli daerah Kota Bitung.

Analisis Kontribusi. Analisis kontribusi adalah analisis yang digunakan untuk mengukur besarnya kontribusi dari pajak daerah terhadap Pendapatan Asli Daerah kota Bitung. Rumus yang digunakan yaitu (Firdausy, 2017:92) : 


$$
\text { Kontribusi Pajak Daerah terhadap PAD }=\frac{\text { Realisasi Pajak Daerah }}{\text { Realisasi PAD }} \text { X 100\% }
$$

Kriteria untuk menilai kontribusi pajak daerah terhadap pendapatan asli daerah yakni:

Tabel 1. Klasifikasi Kriteria Persentase Kontribusi Pajak Daerah

\begin{tabular}{lll}
\hline \multicolumn{1}{c}{ Persentase } & Kriteria \\
\hline $0,00 \%-10 \%$ & Sangat kurang \\
$10,00 \%-20 \%$ & Kurang \\
$20,00 \%-30 \%$ & Sedang \\
$30,00 \%-40 \%$ & Cukup Baik \\
$40,00 \%-50 \%$ & Baik \\
Diatas $50 \%$ & Sangat Baik \\
\hline
\end{tabular}

Sumber: Tim Litbang Depdagri-Fisipol UGM 1991 (Firdausy, 2017:92)

Analisis Efektivitas. Analisis efektivitas dipakai untuk mengukur kinerja pemerintah daerah Kota Bitung dalam usaha mencapai target pajak daerah yang telah ditetapkan. Adapun nilai yang dihitung berdasarkan perbandingan realisasi pajak daerah dengan target pajak daerah dengan menggunakan rumus sebagai berikut (Mahsun, 2012:187):

$$
\text { Efektivitas Pajak Daerah }=\frac{\text { Realisasi Pajak Daerah }}{\text { Target Pajak Daerah }} \text { X 100\% }
$$

Kriteria untuk menilai tingkat efektivitas pajak daerah terhadap pendapatan asli daerah yakni:

Tabel 2. Klasifikasi Kriteria Nilai Efektivitas Pajak Daerah

\begin{tabular}{ll}
\hline \multicolumn{1}{c}{ Persentase } & \multicolumn{1}{c}{ Kriteria } \\
\hline Diatas $100 \%$ & Sangat efektif \\
$90 \%-100 \%$ & Efektif \\
$80 \%-90 \%$ & Cukup efektif \\
$60 \%-80 \%$ & Kurang efektif \\
Kurang dari $60 \%$ & Tidak efektif \\
\hline
\end{tabular}

Sumber: Kepmendagri No.690.900.327 Tahun 1996 (Firdausy, 2017:91)

\section{HASIL PENELITIAN DAN PEMBAHASAN}

\subsection{Hasil Penelitian}

Pajak Daerah Kota Bitung. Pemerintah Kota Bitung dalam hal ini Badan Pengelola Pajak Daerah dan Retribusi Daerah (BP2RD) telah melakukan pemungutan Pajak Daerah berdasarkan pada Peraturan Daerah Nomor 4 Tahun 2017 tentang Pajak Daerah. Adapun pajak yang diatur dalam peraturan daerah ini terdiri dari pajak parkir, pajak hotel, pajak reklame, pajak restoran, pajak air tanah, pajak hiburan, pajak penerangan jalan, pajak sarang burung walet, pajak mineral bukan logam dan batuan, pajak bumi dan bangunan pedesaan dan perkotaan, serta bea perolehan hak atas tanah dan/atau bangunan. Untuk pajak parkir, pajak sarang burung walet serta pajak bumi dan bangunan pedesaan dan perkotaan merupakan tambahan pungutan baru yang dilakukan mulai tahun 2014 oleh pemerintah Kota Bitung. Dibawah ini ialah data pajak daerah Kota Bitung yang didapat dari penelitian di BP2RD, secara garis besar dapat dilihat pada Tabel 3. 
Tabel 3. Realisasi Pajak Daerah Kota Bitung Tahun 2013-2017

\begin{tabular}{crrrr}
\hline \multirow{2}{*}{ Tahun } & \multicolumn{2}{c}{ Target (Rp) } & \multirow{2}{*}{ Realisasi (Rp) } & \multirow{2}{*}{$\%$} \\
\cline { 2 - 3 } & APBD Induk & APBD Perubahan & & \\
\hline 2013 & 16.520 .000 .000 & 16.888 .970 .257 & 26.162 .693 .540 & 154,91 \\
2014 & 29.370 .000 .000 & 29.370 .000 .000 & 33.493 .759 .019 & 114,04 \\
2015 & 31.500 .000 .000 & 32.350 .000 .000 & 37.360 .100 .376 & 115,49 \\
2016 & 32.350 .000 .000 & 32.350 .000 .000 & 35.463 .283 .256 & 109,62 \\
2017 & 35.000 .000 .000 & 36.480 .000 .000 & 48.432 .103 .560 & 132,76 \\
\hline
\end{tabular}

Sumber: Badan Pengelola Pajak dan Retribusi Daerah Kota Bitung

Pendapatan Asli Daerah Kota Bitung. Dibawah ini ialah data penerimaan Pendapatan Asli Daerah Kota Bitung yang didapat dari penelitian di BP2RD, secara garis besar dapat dilihat pada Tabel 4.

Tabel 4. Realisasi Pendapatan Asli Daerah (PAD) Kota Bitung tahun 2013-2017

\begin{tabular}{|c|c|c|c|c|}
\hline \multirow{2}{*}{ Tahun } & \multicolumn{2}{|c|}{ Target (Rp) } & \multirow{2}{*}{ Realisasi (Rp) } & \multirow{2}{*}{$\%$} \\
\hline & APBD Induk & APBD Perubahan & & \\
\hline 2013 & 40.852 .860 .157 & 44.000 .000 .000 & 55.202 .617 .147 & 125,46 \\
\hline 2014 & 57.118 .727 .367 & 71.654 .094 .447 & 83.520 .151 .103 & 116,56 \\
\hline 2015 & 75.000 .000 .000 & 96.000 .000 .000 & 106.133 .530 .054 & 110,56 \\
\hline 2016 & 96.315 .000 .000 & 96.705 .399 .677 & 82.927 .096 .690 & 85,75 \\
\hline 2017 & 103.051 .320 .213 & 116.232 .245 .700 & 122.781 .156 .557 & 105,63 \\
\hline
\end{tabular}

Sumber: Badan Pengelola Pajak dan Retribusi Daerah Kota Bitung

\subsection{Pembahasan}

Analisis Kontribusi Pajak Daerah Kota Bitung

Tabel 5. Kontribusi Pajak Daerah Terhadap PAD Kota Bitung tahun 2013-2017

\begin{tabular}{cccrl}
\hline Tahun & $\begin{array}{c}\text { Realisasi Pajak } \\
\text { Daerah (Rp) }\end{array}$ & $\begin{array}{c}\text { Realisasi PAD } \\
(\mathbf{R p})\end{array}$ & $\begin{array}{c}\text { Persentase } \\
\text { Kontribusi }\end{array}$ & $\begin{array}{c}\text { Kriteria } \\
\text { Kontribusi }\end{array}$ \\
\hline 2013 & 26.162 .693 .540 & 55.199 .680 .147 & 47,39 & Baik \\
2014 & 33.493 .759 .019 & 83.520 .151 .103 & 40,10 & Baik \\
2015 & 37.360 .100 .376 & 106.133 .530 .054 & 35,20 & Cukup Baik \\
2016 & 35.463 .283 .256 & 82.927 .096 .690 & 42,76 & Baik \\
2017 & 48.432 .103 .560 & 122.781 .156 .557 & 39,44 & Cukup Baik \\
& Rata-rata & & $\mathbf{4 0 , 9 8}$ & Baik \\
\hline
\end{tabular}

Sumber: BP2RD Kota Bitung (data diolah)

Dari Tabel 5 dapat diketahui bahwa kontribusi pajak daerah Kota Bitung terhadap PAD dari tahun 2013 sampai dengan tahun 2017 mengalami fluktuasi dengan persentase kontribusi tahun 2013 adalah 47,39\%, tahun 2014 adalah 40,10\%, tahun 2015 adalah 35,20\%, tahun 2016 adalah 42,76\% dan tahun 2017 adalah 39,44\%. Secara umum, rata-rata kontribusi pajak daerah terhadap PAD Kota Bitung masuk dalam kategori baik yaitu sebesar 40,98\% setiap tahun. Pajak daerah dinilai memberikan kontribusi besar jika hasil perhitungannya melebihi 50\%, adapun kontribusi pajak daerah Kota Bitung belum mencapai angka 50\% tiap tahunnya. Ini berarti bahwa pajak daerah Kota Bitung belum memberikan kontribusi yang besar terhadap PAD. 
Dibawah ini ialah rata-rata kontribusi masing-masing jenis pajak daerah yang dipungut oleh pemerintah Kota Bitung selama 5 tahun periode tahun 2013-2017.

Tabel 6. Rata-rata Kontribusi Pajak Daerah Terhadap PAD Kota Bitung tahun 2013-2017

\begin{tabular}{clrl}
\hline No. & \multicolumn{1}{c}{ Jenis Pajak Daerah } & $\begin{array}{c}\text { Rata-rata } \\
\text { Kontribusi }\end{array}$ & Kriteria \\
\hline 1 & Pajak hotel & $2,30 \%$ & Sangat kurang \\
2 & Pajak restoran & $3,07 \%$ & Sangat kurang \\
3 & Pajak hiburan & $0,45 \%$ & Sangat kurang \\
4 & Pajak reklame & $1,09 \%$ & Sangat kurang \\
5 & Pajak penerangan jalan & $15,5 \%$ & Kurang \\
6 & Pajak mineral bukan logam dan batuan & $0,64 \%$ & Sangat kurang \\
7 & Pajak parkir & $0,019 \%$ & Sangat kurang \\
8 & Pajak air tanah & $1,28 \%$ & Sangat kurang \\
9 & Pajak sarang burung walet & $0,003 \%$ & Sangat kurang \\
10 & Pajak bumi dan bangunan pedesaan dan perkotaan & $11,01 \%$ & Kurang \\
11 & Bea perolehan hak atas tanah dan bangunan & $8,79 \%$ & Sangat kurang \\
\hline
\end{tabular}

Sumber: BP2RD Kota Bitung (data diolah)

Berdasarkan Tabel 6 diketahui bahwa secara keseluruhan kontribusi masing-masing jenis pajak daerah berada pada kategori sangat kurang hingga kurang. Kontribusi terbesar berasal dari pajak penerangan jalan dengan rata-rata kontribusi $14,5 \%$ per tahun. Dan kontribusi terendah berasal dari pajak sarang burung walet dengan rata-rata kontribusi $0,003 \%$ per tahun.

\section{Analisis Efektivitas Pajak Daerah Kota Bitung}

Tabel 7. Efektivitas Pajak Daerah Kota bitung Tahun 2013-2017

\begin{tabular}{cccrc}
\hline Tahun & $\begin{array}{c}\text { Realisasi Pajak } \\
\text { Daerah (Rp) }\end{array}$ & $\begin{array}{c}\text { Target Pajak } \\
\text { Daerah (Rp) }\end{array}$ & $\begin{array}{c}\text { Persentase } \\
\text { Efektivitas }\end{array}$ & $\begin{array}{c}\text { Kriteria } \\
\text { Efektivitas }\end{array}$ \\
\hline 2013 & 26.162 .693 .540 & 16.888 .970 .257 & 154,91 & Sangat Efektif \\
2014 & 33.493 .759 .019 & 29.370 .000 .000 & 114,04 & Sangat Efektif \\
2015 & 37.360 .100 .376 & 32.350 .000 .000 & 115,49 & Sangat Efektif \\
2016 & 35.463 .283 .256 & 32.350 .000 .000 & 109,62 & Sangat Efektif \\
2017 & 48.432 .103 .560 & 36.480 .000 .000 & 132,76 & Sangat Efektif \\
& Rata-rata & & $\mathbf{1 2 5 , 3 6}$ & Sangat Efektif \\
\hline
\end{tabular}

Sumber: BP2RD Kota Bitung (data diolah)

Dari Tabel 7 dapat diketahui bahwa tingkat efektivitas pajak daerah Kota Bitung masuk dalam kategori sangat efektif dengan persentase rata-rata sebesar 125,36\%. Efektivitas tahun 2013 adalah 154,91\%, tahun 2014 adalah 114,04\%, tahun 2015 adalah 115,49\%, tahun 2016 adalah 109,62\% dan tahun 2017 adalah 132,76\%. Tahun 2013 merupakan efektivitas pajak daerah tertinggi, sedangkan tahun 2016 adalah efektivitas terendah. Menurut standar yang ditetapkan maka secara umum pemungutan pajak daerah Kota Bitung sudah efektif. Dibawah ini ialah rata-rata efektivitas setiap jenis pajak daerah Kota Bitung selama 5 tahun periode tahun 2013-2017. 
Tabel 8. Rata-rata Kontribusi Pajak Daerah Terhadap PAD Kota Bitung tahun 2013-2017

\begin{tabular}{clrl}
\hline No. & \multicolumn{1}{c}{ Jenis Pajak Daerah } & Rata-rata Efektivitas & Kriteria \\
\hline 1 & Pajak hotel & $114,64 \%$ & Sangat efektif \\
2 & Pajak restoran & $135,29 \%$ & Sangat efektif \\
3 & Pajak hiburan & $115,9 \%$ & Sangat efektif \\
4 & Pajak reklame & $115,82 \%$ & Sangat efektif \\
5 & Pajak penerangan jalan & $110,4 \%$ & Sangat efektif \\
6 & Pajak mineral bukan logam dan batuan & $161,81 \%$ & Sangat efektif \\
7 & Pajak parkir & $95,76 \%$ & Efektif \\
8 & Pajak air tanah & $125,28 \%$ & Sangat efektif \\
9 & Pajak sarang burung walet & $54,33 \%$ & Kurang efektif \\
10 & Pajak bumi dan bangunan pedesaan dan perkotaan & $112,65 \%$ & Sangat efektif \\
11 & Bea perolehan hak atas tanah dan bangunan & $175,45 \%$ & Sangat efektif \\
\hline
\end{tabular}

Sumber: BP2RD Kota Bitung (data diolah)

Berdasarkan tabel 8 diketahui bahwa selama 5 tahun secara keseluruhan efektivitas setiap jenis pajaknya berada pada kategori kurang hingga sangat efektif. Efektivitas dengan kategori kurang efektif adalah Pajak Sarang Burung Walet sebesar 54,33\%. Efektivitas dengan kategori efektif adalah Pajak Parkir sebesar 95,76\%. Sedangkan efektivitas dengan kategori sangat efektif adalah Pajak Hotel sebesar 114,64\%, Pajak Restoran sebesar 135,29\%, Pajak Hiburan sebesar 115,9\%, Pajak Reklame sebesar 115,82\%, Pajak Penerangan Jalan sebesar 110,4\%, Pajak Mineral Bukan Logam dan Batuan sebesar 161,81\%, Pajak Air Tanah sebesar 125,28, BPHTB sebesar 112,65\% dan PBB-P2 sebesar 175,45\%.

\section{KESIMPULAN DAN SARAN}

\subsection{Kesimpulan}

Berdasarkan hasil penelitian dan pembahasan, maka dapat disimpulkan bahwa:

1. Kontribusi pajak daerah sebagai sumber Pendapatan Asli Daerah (PAD) Kota Bitung selama periode tahun 2013-2017 secara umum berada dalam kategori cukup hingga baik dengan persentase kontribusi antara $35,20 \%$ sampai 47,39\%. Walaupun tingkat kontribusinya masih dibawah 50\%, akan tetapi penerimaan pajak daerah Kota Bitung selalu menunjukkan peningkatan setiap tahun dan selalu mencapai target yang ditetapkan. Dari 11 jenis pajak yang dipungut oleh pemerintah Kota Bitung, pajak pajak penerangan jalan memberikan kontribusi terbesar dengan kontribusi rata-rata yakni 14,5\% dan pajak yang memberikan kontribusi terendah adalah pajak sarang burung walet dengan rata-rata kontribusi $0,003 \%$.

2. Efektivitas pajak daerah sebagai sumber Pendapatan Asli Daerah (PAD) Kota Bitung selama periode tahun 2013-2017 secara umum berada dalam kategori sangat efektif dengan persentase efektivitas antara 109,62\% hingga 154,91\%. Ini berarti bahwa selama lima tahun terakhir pemungutan pajak daerah Kota Bitung sudah berjalan secara efektif. Adapun efektivitas setiapg jenis pajak daerah Kota Bitung masuk pada kategori kurang efektif (pajak sarang burung walet), kategori efektif (pajak parkir) dan kategori sangat efektif (pajak hotel, restoran, hiburan, reklame, pajak penerangan jalan, pajak mineral bukan logam dan batuan, pajak air tanah, BPHTB dan PBB-P2).

\subsection{Saran}

1. Besarnya penerimaan masing-masing jenis pajak daerah perlu ditingkatkan dan dioptimalkan lagi sehingga dapat memberikan kontribusi dan efektivitas yang besar terhadap Pendapatan Asli Daerah. 
2. Pentingnya kualitas SDM/aparatur pemerintah daerah untuk ditingkatkan agar kinerja yang ada menjadi handal dan profesional dalam menggali serta mengelola potensi Pendapatan Asli Daerah yang ada.

3. Perlunya membangun kerjasama yang baik dengan dinas-dinas terkait dalam rangka mengoptimalkan Pendapatan Asli Daerah khususnya sumber pajak daerah.

4. Meningkatkan sosialisasi kepada masyarakat bahwa pentingnya kesadaran dan tanggung jawab dalam membayar pajak guna pembangunan daerah.

\section{DAFTAR PUSTAKA}

Anggoro, Damas. 2017. Pajak Daerah dan Retribusi Daerah. UB Press. Malang.

Direktorat Jenderal Bina Keuangan Daerah Kementerian Dalam Negeri. 2016. Postur APBD. http://www.keuda.kemendagri.go.id/datin/index/1/2016. 28 Agustus 2018 (11:20).

Firdausy, Carunia M. (Ed). 2017. Optimalisasi Kebijakan Pemerintah Daerah. Yayasan Pustaka Obor Indonesia. Jakarta.

Kamus Besar Bahasa Indonesia. Online. https://kbbi.web.id. 11 Juli 2018 (22:10).

Mahmudi. 2010. Analisis Laporan Keuangan Pemerintah Daerah. Sekolah Tinggin Ilmu Manajemen. Yogyakarta.

Mahsun, Mohamad. 2012. Pengukuran Kinerja Sektor Publik. Edisi Pertama. Cetakan Ketiga. BPFE. Yogyakarta.

Octovido, Irsandy, Nengah Sudjana, dan D.F. Azizah. 2014. Analisis Efektivitas dan Kontribusi Pajak Daerah Sebagai Sumber Pendapatan Asli Daerah Kota Batu (Studi Pada Dinas Pendapatan Daerah Kota Batu Tahun 2009-2013. Jurnal Administrasi Bisnis 15(1).

Peraturan Daerah Kota Bitung Nomor 4 Tahun 2017 Tentang Pajak Daerah.

Puspitasari, E.R.A., dan Abdul Rohman. 2014. Analisis Efektivitas, Efisiensi, dan Kontribusi Pajak dan Retribusi Daerah Terhadap Peningkatan PAD Kabupaten Blora Tahun 2009-2013. Jurnal Akuntansi Diponegoro 3(4).

Supramono, dan T.W. Damayanti. 2010. Perpajakan Indonesia, Mekanisme dan Perhitungan. Edisi 1. Andi. Yogyakarta.

Sodikin, Slamet, dan B. Riyono. 2016. Akuntansi Pengantar 1. Edisi Kesembilan. Cetakan Kedua. UPP STIM YKPN. Yogyakarta.

Undang-Undang Republik Indonesia Nomor 16 Tahun 2009 Tentang Ketentuan Umum Perpajakan. 